\title{
Marcin Wierzbiński
}

Uniwersytet Ekonomiczny we Wrocławiu

e-mail: marcin.wierzbinski@ue.wroc.pl

\section{SYSTEM DEMAND SIDE MANAGEMENT W ZARZĄDZANIU KOSZTAMI}

\section{DEMAND SIDE MANAGEMENT IN COST MANAGEMENT}

DOI: $10.15611 / \mathrm{pn} .2019 .544 .24$

JEL Classification - M19

Streszczenie: Autor podejmuje w tym artykule problem dotyczący możliwości informatycznego wspomagania zarządzania stroną popytową (Demand Side Management - DSM) na określony produkt na przykładzie sektora energii elektrycznej. Celem artykułu jest przedstawienie związku pomiędzy koncepcją zarządzania stroną popytową na określony wyrób bądź usługę a wpływaniem na efektywność wykorzystania zasobów przedsiębiorstwa, co ma ścisły związek z zarządzaniem kosztami. W pierwszej części artykułu została przedstawiona istota zarządzania kosztami. W kolejnej części zaprezentowano zakres systemu zarządzania stroną popytową na przykładzie sektora energii elektrycznej. W trzeciej części artykułu zaprezentowano możliwości wykorzystania narzędzi z obszaru DSM w operacyjnym i strategicznym zarządzaniu kosztami.

Słowa kluczowe: zarządzanie stroną popytową, zarządzanie kosztami.

Summary: In the article the author tries to scrutinize the problem regarding Demand Side Management in energy industry. The aim of the article is to prove that demand side management can support the cost management and as a consequence the effectiveness of the company. In the first part of the article cost management practices were presented. Then, there was presented the essence of Demand Side Management, in particular in energy industry. After that it was shown how Demand Side Management can support the increase of the utilization of company's capacity and, as a consequence, the increase of effectiveness. DSM's aim is to shift the demand on a product in time which can translate into the reduction of capacity required to meet the whole demand. As a consequence capacity utilization ratio rises as well as fixed costs related to capacity are reduced. In the last part of the article there were presented the possibilities of usage of DSM in other sectors in particular in SmartCity solutions.

Keywords: Demand Side Management, cost management. 


\section{Wstęp}

Rozwój metod zarządzania kosztami jest ściśle związany z rozwojem rachunku kosztów. Potrzeba rozwinięcia metod rachunku kosztów pojawiła się wraz z początkiem rewolucji przemysłowej w XIX wieku. Dynamicznie rozwijające się przedsiębiorstwa, szczególnie w branży włókienniczej, hutniczej i transportu kolejowego, wymagały odpowiedniego zasilania informacyjnego, dotyczącego ponoszonych kosztów. W tym właśnie czasie wykształcił się system rachunku kosztów pełnych, w tym zasady pomiaru, ewidencji i rozliczania kosztów. Rozwój rachunku kosztów w XIX wieku został szczegółowo przedstawiony między innymi w opracowaniu pt. Zarzadzanie kosztami [Wierzbiński 2017]. Istotnym dokonaniem w ramach rachunku kosztów na przełomie XIX i XX wieku było opracowanie statystycznych metod podziału kosztów na koszty stałe i zmienne, co doprowadziło do powstania rachunku kosztów zmiennych. Wyodrębnienie kosztów stałych i zmiennych było na tyle istotnym osiągnięciem, iż uznano je za podstawowy paradygmat rachunkowości zarządczej [Nita 2008]. Podział kosztów na stałe i zmienne jest podstawą instrumentów wspierających podejmowanie decyzji w krótkim okresie. Na początku $\mathrm{XX}$ wieku nastąpił rozwój masowej produkcji wielu produktów, który wymuszał poszukiwanie nowych metod wspomagających zarządzanie coraz bardziej złożonymi przedsiębiorstwami. Jednym z pierwszych, który podejmował próby podniesienia efektywności masowej produkcji, był F. Taylor, twórca tzw. naukowego zarządzania. F. Taylor opracował metodę doskonalenia pracy, ukierunkowaną na skracanie czasu wykonywania czynności przez pracowników i zwiększanie wydajności, co miało ścisły związek z wpływaniem na wysokość ponoszonych kosztów. Zasady naukowego zarządzania stały się podstawą opracowania rachunku kosztów standardowych. Powstanie koncepcji zarządzania kosztami niewątpliwie należy łączyć z rozwojem rachunku kosztów standardowych. Definicję zarządzania kosztami sformułował m.in. E. Nowak w Rachunek kosztów a zarządzanie kosztami. Rozważanie o relacjach [Nowak 2015]. Według tego autora zarządzanie kosztami jest koncepcją zarządzania obejmującą działania ukierunkowane na poprawę efektywności wykorzystania zasobów przedsiębiorstwa. Z kolei, aby można było podejmować działania wpływające na racjonalizację kosztów, należy posiadać odpowiednie informacje o kosztach, których najważniejszym źródeł jest rachunek kosztów.

W kolejnych dekadach XX wieku następował szybki rozwój metod zarządzania kosztami. Przede wszystkim w latach 50. i 60. XX wieku zostały rozwinięte metody budżetowania kosztów i kontroli zarządczej. Następnie badano także wpływ kontroli bazującej na budżetach kosztów na zachowania pracowników, co doprowadziło do poddania krytyce tradycyjnych metod budżetowania. W wyniku tego pojawiły się koncepcje zarządzania, które nie bazowały na budżetach kosztów (beyond budgeting). $\mathrm{Z}$ kolei w tym samym czasie w kręgu gospodarczym Japonii powstały takie metody zarządzania kosztami, jak:

- rachunek kosztów docelowych (target costing), 
- rachunek kosztów ciągłego doskonalenia (kaizen costing),

- system zarządzania zapasami dokładnie na czas (just-in-time),

- system sterowania produkcją kanban.

W końcu XX wieku tradycyjne metody rachunku kosztów zostały poddane ostrej krytyce. W szybko zmieniającym się i globalizującym świecie metody te nie dostarczały użytecznych informacji, potrzebnych do zarządzania kosztami przedsiębiorstwa. Nowe podejście wymagało zastosowania orientacji procesowej w zarządzaniu kosztami. Odpowiedzią na to zapotrzebowanie było opracowanie przez R.S. Kaplana i R. Coopera rachunku kosztów działań [Kaplan, Cooper 2000], który dostarcza informacji niezbędnych do zarządzania kosztami działań. Rachunek kosztów działań dał także początek takim metodom zarządzania kosztami, jak:

- podejście procesowe do zarządzania kosztami,

- rachunek i analiza kosztów łańcucha wartości,

- zarządzanie kosztami jakości,

- zarządzanie kosztami klienta,

- integracja zarządzania kosztami z innymi obszarami przedsiębiorstwa podlegającymi zarządzaniu, między innymi poprzez wykorzystanie szeregu kart dokonań, w tym głównie strategicznej karty wyników.

Cechą szczególną rozwoju metod zarządzania kosztami w XXI wieku jest ich integracja z innymi metodami zarządzania przedsiębiorstwem, a także wspomaganie zarządzania kosztami przez technologie informatyczne. Celem tego artykułu jest przedstawienie związku pomiędzy koncepcją zarządzania stroną popytową na określony wyrób bądź usługę a wpływaniem na efektywność wykorzystania zasobów przedsiębiorstwa, co ma ścisły związek z zarządzaniem kosztami. Zarządzanie stroną popytową na określony wyrób bądź usługę jest wspierane najczęściej przez systemy informatyczne typu Demand Side Management, które wykorzystują koncepcję cen dynamicznych i Internetu rzeczy (Internet of Things). Tego typu systemy rozwijają się w przedsiębiorstwach z sektora utilities, w tym głównie branży energetycznej, ciepłowniczej i wodociągowej. Niemniej jednak koncepcja zarządzania stroną popytową na określony produkt znajduje również coraz szersze zastosowanie w innych branżach, m.in. w turystycznej, hostingowej, usług parkingowych, w tym usług świadczonych w ramach Smart City, i wielu innych.

\section{Istota zarządzania stroną popytową w sektorze energii elektrycznej}

Pojęcie zarządzania stroną popytową (Demand Side Managament - dalej DSM) wywodzi się z rynku energii elektrycznej. Pierwszy definicję DSM sformułował C.W. Gellings w latach 80. ubiegłego wieku [Gellings 1985, za: Warren 2014]. Przez DSM należy rozumieć działania podejmowane w sposób bezpośredni lub pośredni po stronie odbiorców energii elektrycznej (strona popytowa), które są stymulowane przez dostawcę tego produktu. Celem DSM jest przede wszystkim redukcja 
zapotrzebowania na moc elektryczną w okresach (godzinach) szczytowego jej poboru przy zachowaniu całkowitego popytu na ten produkt w ciągu dłuższego okresu (doby, miesiąca, roku) bez zmian lub nawet przy zwiększeniu sprzedaży tego produktu. Cel ten można osiągnąć poprzez przesunięcie poboru energii elektrycznej z okresów (godzin) szczytowego zapotrzebowania na nią na okresy (godziny), w których zapotrzebowanie na moc elektryczną jest mniejsze. Ogólna idea DSM została zaprezentowana na rysunku 1.

Przed wdrożeniem systemu DSM szczytowe zapotrzebowanie na energię elektryczną w ciągu doby (najczęściej występują dwa szczyty: przedpołudniowy i popołudniowy) jest znacznie wyższe niż po wdrożeniu rozpatrywanego systemu. Implementacja systemu DSM przyczynia się do „spłaszczenia” zapotrzebowania na moc elektryczną przez odbiorcę w ciągu doby. Widoczne jest wyraźne przesunięcie przez odbiorcę zapotrzebowania na moc elektryczną z okresów szczytowych na godziny charakteryzujące się mniejszym zapotrzebowaniem na moc.

Wdrożenie systemu DSM w dużej skali, tj. u dużej liczby odbiorców końcowych, ma wpływ na obciążenie mocą całego systemu elektroenergetycznego, a także na obciążenie mocą poszczególnych źródeł energii w nim pracujących. Przed wdrożeniem DSM uporządkowany wykres obciążenia mocą danego źródła energii w ciągu doby wykazuje znacznie wyższe zapotrzebowanie na moc w szczycie niż po wdrożeniu DSM. Jednocześnie po wdrożeniu DSM w dużej skali następuje zazwyczaj zwiększenie zapotrzebowania na moc elektryczną w godzinach pozaszczytowych. Dzięki temu widoczne jest spłaszczenie zapotrzebowania na moc elektryczną w źródle, co bezpośrednio przekłada się na poprawę warunków eksploatacyjnych źródła.

System DSM może być wdrażany przy wykorzystaniu różnych narzędzi i polityk, a także przez różne podmioty działające $\mathrm{w}$ ramach rynku energii elektrycznej, co zaprezentowano na rysunku 2.

W ramach DSM wykorzystywane są najczęściej następujące narzędzia:

- zmiana zachowania odbiorców poprzez wykorzystanie bodźców ekonomicznych,

- magazynowanie energii elektrycznej po stronie odbiorców końcowych,

- wykorzystanie rozproszonych źródeł energii do ograniczenia poboru mocy przez odbiorców w warunkach szczytowego zapotrzebowania na nią,

- podnoszenie efektywności energetycznej.

Pierwszy z wymienionych mechanizmów jest bezpośrednio związany z przesunięciem przez odbiorców końcowych poboru energii elektrycznej z okresów szczytowego zapotrzebowania na nią na okresy, w których to zapotrzebowanie jest mniejsze. Zmiana zachowania może polegać na:

- czasowym obniżeniu poboru mocy przez określone urządzenia, co dotyczy przede wszystkim zakładów przemysłowych,

- przesunięciu w czasie wykonywania określonych czynności, z którymi jest związane uruchomienie określonych urządzeń, co może być realizowane zarówno przez zakłady przemysłowe, jak i gospodarstwa domowe. 


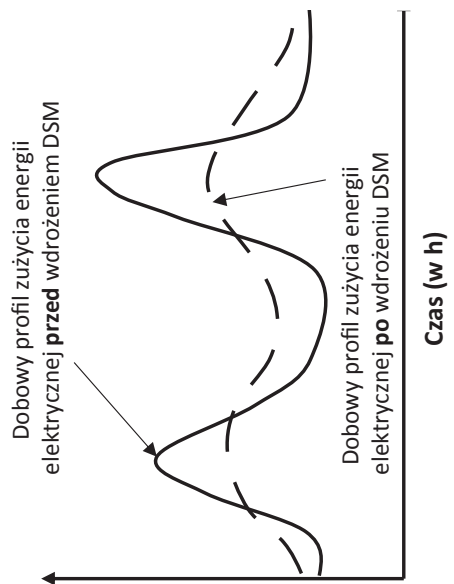

(MY M) Kэou soqod

Skala wdrożenia DSM po stronie odbiorców końcowych

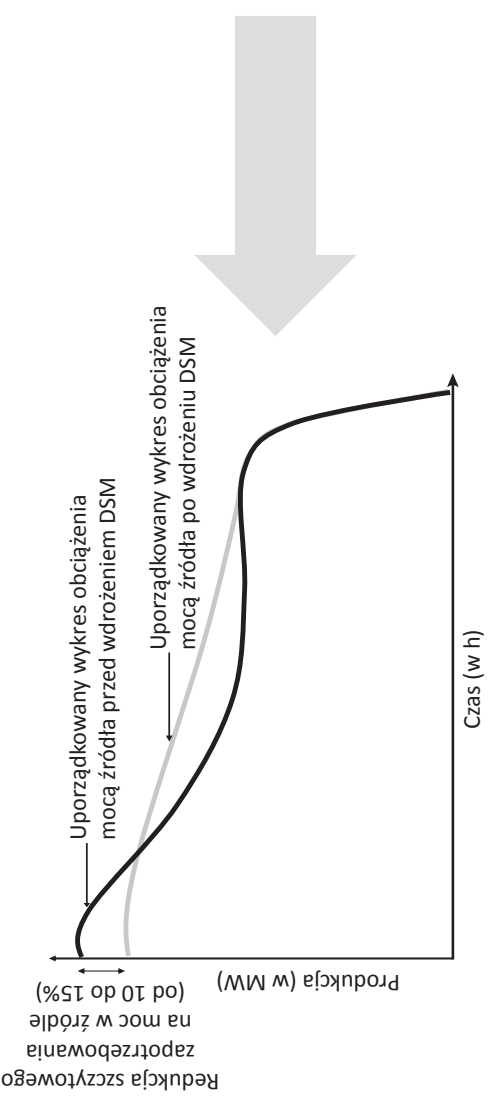

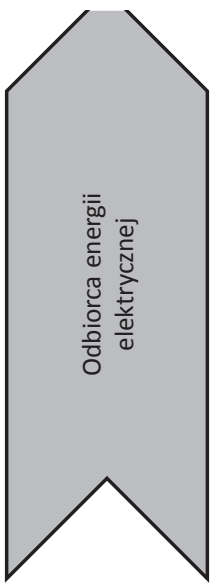

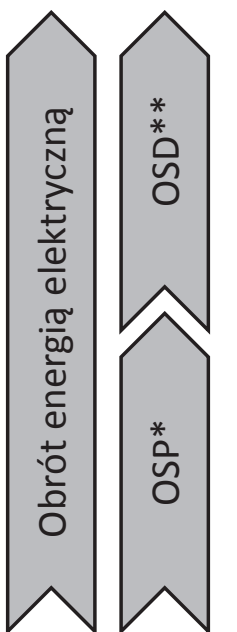

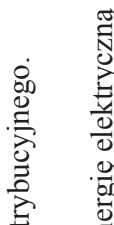

㫄

릴

क

क

흄

荧

ก)

๑

0

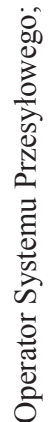

. ํㅡㄹ

స్

N

营

군

Ð

을

范

$\dot{\vec{\lambda}}$ 


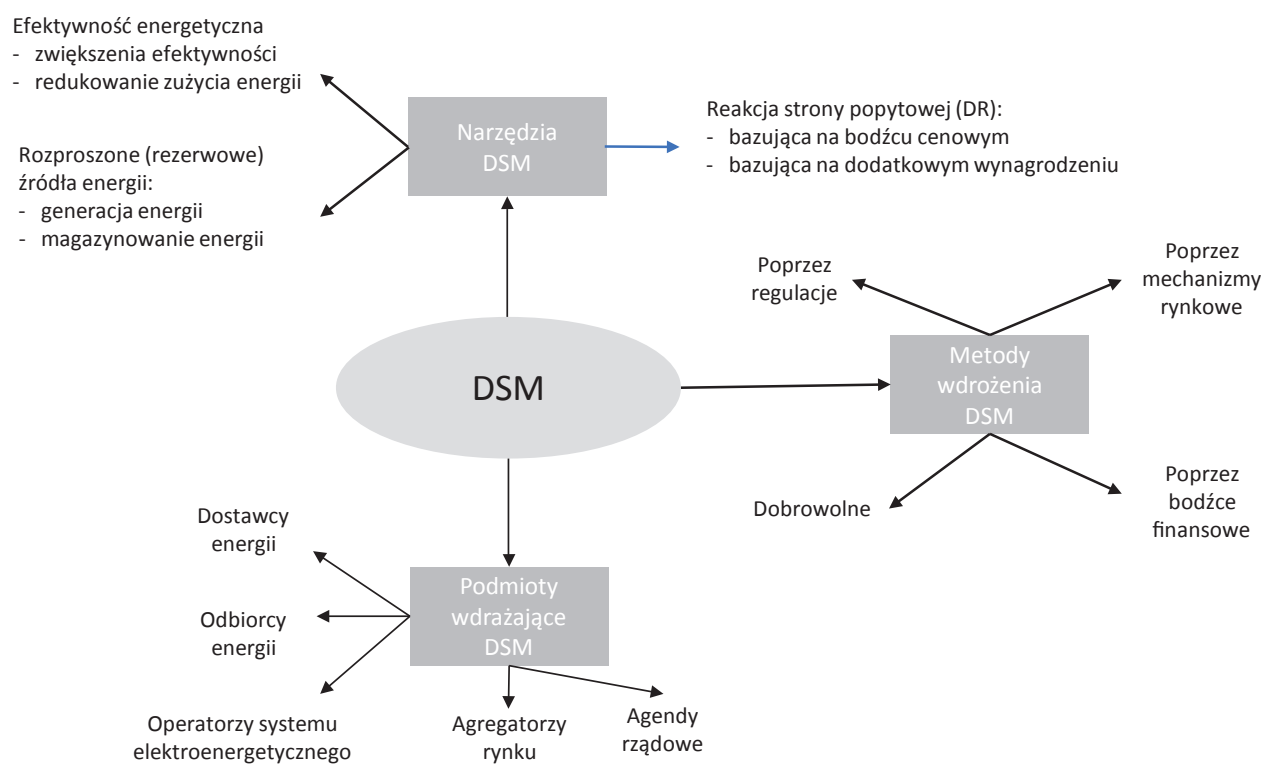

Rys. 2. Metody i narzędzia DSM

Źródło: [Warren 2014].

Przed wdrożeniem DSM przeprowadza się kategoryzację czynności i urządzeń pod względem możliwości przesunięcia zapotrzebowania na moc elektryczną w ciągu doby czy tygodnia. W gospodarstwach domowych kategoryzacja czynności i związanych z nimi urządzeń, które są powiązane z DSM, może przedstawiać się następująco:

- czynności, które mogą być przesunięte w ciągu doby z perspektywy poboru energii elektrycznej (uruchomienie zmywarki, pralki, suszarki, prasowanie etc.),

- czynności, które nie mogą być lub są trudne do przesunięcia w ciągu doby z perspektywy poboru energii elektrycznej (oświetlenie, oglądanie telewizji).

Podobnie w przedsiębiorstwach produkcyjnych, handlowych i usługowych można zidentyfikować czynności - i wykorzystywane w ich ramach urządzenia - których wykonywanie może zostać przesunięte w czasie bez szkody dla wielkości czy jakości produkcji bądź świadczonych usług. Zarówno zakłady przemysłowe, jak i gospodarstwa domowe, kategoryzując czynności i powiązane z nimi urządzenia, mogą przesuwać w czasie część zapotrzebowania na moc elektryczną, co prowadzi do zmiany ich profilów poboru energii elektrycznej.

W celu stymulowania odpowiedniego zachowania odbiorców dostawcy energii elektrycznej wykorzystują określone bodźce ekonomiczne. Bodźce te można podzielić na dwie zasadnicze grupy:

- bonifikaty lub specjalne premie wypłacane w zamian za zmniejszenie poboru energii elektrycznej w okresach szczytowego zapotrzebowania na nią, 
- ceny dynamiczne, których wysokość jest uzależniona od popytu i podaży energii elektrycznej w określonych godzinach lub dłuższych okresach doby. Przykład premii wypłacanych w ramach systemu DSM zaprezentowano w tabeli 1.

Tabela 1. Przykłady premii i bonifikat dla odbiorców biorących udział w systemie DSM

\begin{tabular}{|l|l|l|}
\hline \multicolumn{1}{|c|}{$\begin{array}{c}\text { Rodzaj wynagrodzenia dla odbiorcy } \\
\text { za obniżenie mocy }\end{array}$} & $\begin{array}{c}\text { Przykładowy czas pomiędzy } \\
\text { otrzymaniem informacji przez odbiorcę } \\
\text { od operatora systemu o konieczności } \\
\text { obniżenia mocy a rzeczywistą } \\
\text { reakcję odbiorcy }\end{array}$ & $\begin{array}{c}\text { Minimalne } \\
\text { wymagania } \\
\text { dotyczące } \\
\text { obniżenia mocy }\end{array}$ \\
\hline $\begin{array}{l}\text { Miesięczna stawka stała za } \\
\text { zadeklarowany przez odbiorcę MW } \\
\text { obniżenia mocy, niezależnie od liczby } \\
\text { wykorzystanych obniżen }\end{array}$ & $\begin{array}{l}\text { Wyprzedzenie godzinowe } \\
1 \mathrm{MW} \\
\text { do } 4 \text { godzin }\end{array}$ \\
\hline $\begin{array}{l}\text { Stawka za MWh rzeczywistego } \\
\text { obniżenia poboru energii elektrycznej }\end{array}$ & Wyprzedzenie godzinowe & $\begin{array}{l}1 \mathrm{MW} \\
\text { do } 4 \text { godzin }\end{array}$ \\
\hline $\begin{array}{l}\text { Stawka miesięczna za MW za gotowość } \\
\text { świadczenia usługi } \\
\text { oraz } \\
\text { stawka za MWh rzeczywistego } \\
\text { obniżenia poboru energii elektrycznej }\end{array}$ & Wyprzedzenie 30 minut & $\begin{array}{l}1 \mathrm{MW} \\
\text { do } 4 \text { godzin }\end{array}$ \\
\hline $\begin{array}{l}\text { Obniżenie o określony proc. stawek za } \\
\text { zakontraktowaną energię elektryczną }\end{array}$ & Wyprzedzenie dobowe & $\begin{array}{l}5 \text { MW } \\
\text { do } 6 \text { godzin }\end{array}$ \\
\hline
\end{tabular}

Źródło: opracowanie własne na podstawie [Tuan, Bhattacharya 2003].

W większości systemów DSM opartych na premiach wypłacanych odbiorcom wykorzystuje się stałe wynagrodzenia miesięczne dla odbiorcy końcowego za każdy zadeklarowany MW obniżenia mocy po otrzymaniu wyprzedzającej informacji. Wdrożenie wynagrodzeń bazujących na dodatkowej płatności za każdą niepobraną MWh w warunkach szczytowego zapotrzebowania na moc jest trudne ze względu na problemy z określeniem ilości unikniętego poboru energii elektrycznej.

Bardziej zaawansowane systemy DSM bazują na cenach dynamicznych za energię elektryczną. W tych systemach cena energii elektrycznej dla odbiorców końcowych zmienia się w każdej godzinie doby w zależności od popytu i podaży. Innymi słowy, w tych systemach uwarunkowania cenowe z rynku hurtowego są przekładane przez sprzedawców energii elektrycznej na odbiorców końcowych. O ile duzi odbiorcy przemysłowi mogą się samodzielnie zaopatrywać w energię elektryczną na rynku hurtowym, a zatem korzystają z cen dynamicznych od dłuższego czasu, o tyle mniejsze przedsiębiorstwa i gospodarstwa domowe tym systemem kształtowania cen mogą być objęte wyłącznie w przypadku dokonania się określonych zmian w prawie i w obszarze technologicznym (np. inteligentne opomiarowanie).

Jeżeli zachowania odbiorców w zakresie poboru energii elektrycznej zmieniają się pod wpływem bodźców ekonomicznych, to mieszczą się one w ramach poję- 
cia reakcji strony popytowej (Demand Response). Mechanizmy Demand Response mieszczą się w szeroko pojętym DSM.

Efektywne zarządzanie stroną popytową na energię elektryczną zawiera w sobie także wykorzystywanie magazynów energii i rozproszonych źródeł energii, instalowanych przez odbiorców końcowych, do spłaszczania profilu poboru mocy przez nich z systemu elektroenergetycznego. Domowe magazyny energii są coraz bardziej popularne, szczególnie z jednoczesną instalacją fotowoltaiki. Magazyn energii jest ładowany w godzinach niskiego zapotrzebowania na moc elektryczną, w których występują niższe ceny energii elektrycznej, a następnie zgromadzona w nich energia jest wykorzystywana w okresach szczytowego poboru mocy w systemie, kiedy ceny energii elektrycznej są najwyższe. Energię elektryczną można także magazynować w postaci gorącej wody wykorzystywanej do celów użytkowych lub do ogrzewania pomieszczeń. Wreszcie w systemach DSM są wykorzystywane rozproszone źródła energii, szczególnie takie, które mogą zostać w szybkim tempie przywołane do pracy i odstawione w stan spoczynku. Do tych urządzeń zalicza się przede wszystkim agregaty na gaz ziemny lub olej napędowy, które w zakładach przemysłowych lub szpitalach stanowią rezerwowe źródło energii.

Niektórzy autorzy w ramach koncepcji DSM uwzględniają także podnoszenie efektywności energetycznej po stronie odbiorców końcowych. O ile celem wymienionych wcześniej metod zarząazzania popytem jest przesunięcie poboru energii elektrycznej w czasie, o tyle celem podnoszenia efektywności energetycznej jest zmniejszenie ogólnego zużycia tego produktu przy zachowaniu tego samego poziomu jakości życia lub tego samego poziomu produkcji. Podnoszenie efektywności energetycznej może jednak wpłynąć na ogólny popyt na energię elektryczną, w tym także w okresach jej szczytowego poboru, co przekłada się ostatecznie na redukcję zapotrzebowania na moc również w tych okresach.

Systemy DSM mogą być wdrażane przez różne podmioty z łańcucha wartości produkcji, dostawy i sprzedaży energii elektrycznej. Do tej pory najczęściej wdrożenie systemu DSM było inicjowane, a następnie realizowane przez operatorów systemów elektroenergetycznych lub dystrybucyjnych, którzy byli również odpowiedzialni za opracowanie procedur związanych z funkcjonowaniem tego systemu. $\mathrm{W}$ ostatnim czasie rozwija się jednak szereg nowych modeli biznesowych na rynku DSM. Jednym z bardziej popularnych jest model agregatora rynku redukcji zapotrzebowania na moc, który jest swego rodzaju pośrednikiem pomiędzy odbiorcami końcowymi uczestniczącymi w systemie a operatorem systemu elektroenergetycznego bądź dystrybucyjnego.

Konkludując część dotyczącą istoty DSM, to koncepcja ta obejmuje szeroko pojętą efektywność energetyczną i mechanizmy Demand Response [Behrangrad 2015; Sharifi, Fathi, Vahidinasab 2017]. Narzędzia DSM mogły się rozwinąć intensywnie w ostatnich latach dzięki postępowi technologicznemu, szczególnie w takich obszarach, jak technologie telekomunikacyjne, sterowania i kontroli, Internetu rzeczy. Dzięki wymienionym technologiom zarządzanie stroną popytową na energię elek- 
tryczną staje się coraz bardziej zautomatyzowane, a zatem również skuteczne. Rozwój i wdrażanie tych technologii przekłada się także na to, iż przesunięcia w popycie na energię elektryczną mogą się odbywać w zasadzie w sposób niepogarszający jakości życia odbiorców tego produktu.

\section{DSM a zarządzanie kosztami}

Wdrożenie systemu DSM bezpośrednio wiąże się zarządzaniem kosztami i wynikami. W przypadku przedsiębiorstw z sektora energetycznego system DSM ma największy wpływ na koszty oraz wyniki wytwórców energii elektrycznej. W pewnym zakresie systemy DSM mogą również oddziaływać na przychody ze sprzedaży.

Wdrożenie systemu DSM przekłada się na przesunięcie popytu na energię elektryczną z okresów, w których występuje szczytowe zapotrzebowanie na nią, na okresy (godziny w ciągu doby) charakteryzujące się mniejszym popytem. Na rynku hurtowym energii elektrycznej przesunięcie to będzie widoczne pod warunkiem wdrożenia systemu DSM w dużej skali (przez dużą liczbę odbiorców końcowych). Przy dużej skali wdrożenia systemu DSM przesunięcie popytu na energię elektryczną będzie wywierało wpływ na ceny energii elektrycznej na rynku hurtowym.

Po objęciu systemem DSM znaczącej liczby odbiorców końcowych ceny energii elektrycznej spadną w okresach szczytowego zapotrzebowania na nią i jednocześnie nieco wzrosną w godzinach poza szczytem popytu. Wdrożenie systemów DSM może oddziaływać nie tylko na wysokość cen energii elektrycznej w poszczególnych godzinach doby, ale także na sumaryczny popyt na energię elektryczną w ciągu doby czy dłuższego okresu. Oddziaływanie na popyt może być widoczne wówczas, gdy wdrożenie systemu DSM jest związane z przełożeniem cen dynamicznych z rynku hurtowego na odbiorców końcowych, co obecnie jest rozwiązaniem rzadkim, niemniej jednak rozwój technologii, w tym inteligentnego opomiarowania, umożliwi takie rozwiązania w przyszłości. Jeżeli przed wdrożeniem dynamicznych cen dla odbiorców końcowych były im oferowane stałe ceny energii elektrycznej w ciągu doby, to po wprowadzeniu cen dynamicznych mogą oni zwiększyć pobór energii elektrycznej w okresach (godzinach) z najniższymi cenami (poza szczytem) ponad poziom wynikający z przesunięcia energii elektrycznej z godzin szczytowych. W ten sposób całkowity popyt na energię elektryczną w ciągu doby zwiększy się, a zatem także przychody wytwórców.

Wdrożenie systemu DSM oddziałuje także na koszty wytwórców energii elektrycznej. Z perspektywy zarządzania kosztami wdrożenie systemu DSM w dużej skali ma wymiar zarówno operacyjny, jak i strategiczny.

W krótkim okresie przesunięcie popytu na energię elektryczną z godzin o najwyższym zapotrzebowaniu na godziny o zapotrzebowaniu niższym oddziałuje na rozdział obciążeń pomiędzy jednostki wytwórcze (bloki) w źródle. Przy rozdziale obciążeń (produkcji) pomiędzy jednostki wytwórcze w źródle bierze się pod uwagę: 
- koszty krańcowe wytwarzania energii elektrycznej przez poszczególne bloki, którymi w krótkim okresie są koszty jednostkowe zmienne,

- ograniczenia techniczne, w tym maksymalną i minimalną moc elektryczną bloków, szybkość zwiększania i ograniczania mocy bloków, plan remontów i odstawień itp.

Rozdzielając obciążenia pomiędzy poszczególne bloki, układa się je hierarchicznie - od bloków o najniższych kosztach jednostkowych zmiennych, aż po bloki charakteryzujące się najwyższymi kosztami jednostkowymi zmiennymi. W przypadku bloków opalanych tym samym paliwem koszty jednostkowe zmienne będą uzależnione od poziomu ich sprawności.

Przykładowa zmiana rozdziału obciążeń (wielkości produkcji) pomiędzy bloki po wdrożeniu systemu DSM w dużej skali została zaprezentowana na rysunku 3.

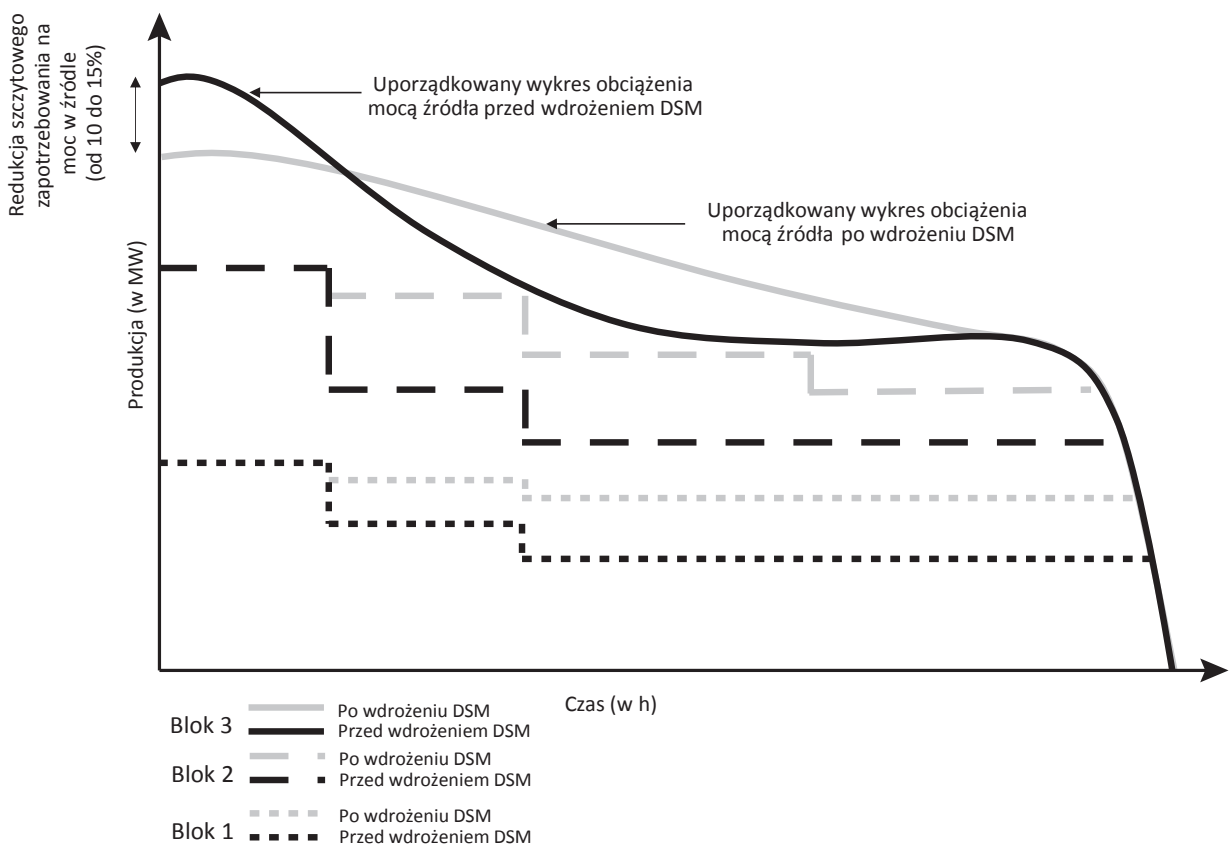

Rys. 3. Przykładowa zmiana obciążenia bloków w źródle energii po wdrożeniu systemu DSM Źródło: opracowanie własne.

Niezależnie od wdrożenia systemu DSM w krótkim okresie przy rozdziale obciążeń (produkcji) pomiędzy bloki dąży się do maksymalnego obciążenia i do jak najdłuższego czasu pracy jednostek wytwórczych o najniższych kosztach jednostkowych zmiennych. Z tego powodu jednostki te pracują w podstawie obciążenia, natomiast jednostki wytwórcze o najwyższych kosztach jednostkowych zmiennych pracują w szczycie, „domykając” niejako zapotrzebowanie na moc w poszczególnych godzinach doby. 
Po wdrożeniu systemu DSM w dużej skali następuje przesunięcie popytu na energię elektryczną w czasie, o czym była mowa wcześniej, co przekłada się na „spłaszczenie" wykresu uporządkowanego obciążeń danego źródła w ciągu doby. Spłaszczenie to sprzyja wydłużeniu czasu pracy z większą mocą jednostek wytwórczych o najniższych kosztach jednostkowych zmiennych, pracujących w podstawie obciążenia. Wzrost mocy tych jednostek przekłada się także na podniesienie ich sprawności i dalsze obniżenie kosztu jednostkowego zmiennego produkcji energii elektrycznej. Jednocześnie „spłaszczenie” wykresu uporządkowanego przekłada się na ograniczenie czasu pracy z wyższą mocą jednostek wytwórczych o najwyższych kosztach jednostkowych zmiennych. Te zmiany rozdziału obciążeń, przy założeniu, że całkowity popyt na energię elektryczną po wdrożeniu systemu DSM nie zmienia się, powodują ograniczenie całkowitych kosztów zmiennych źródła zgodnie z rysunkiem 4.
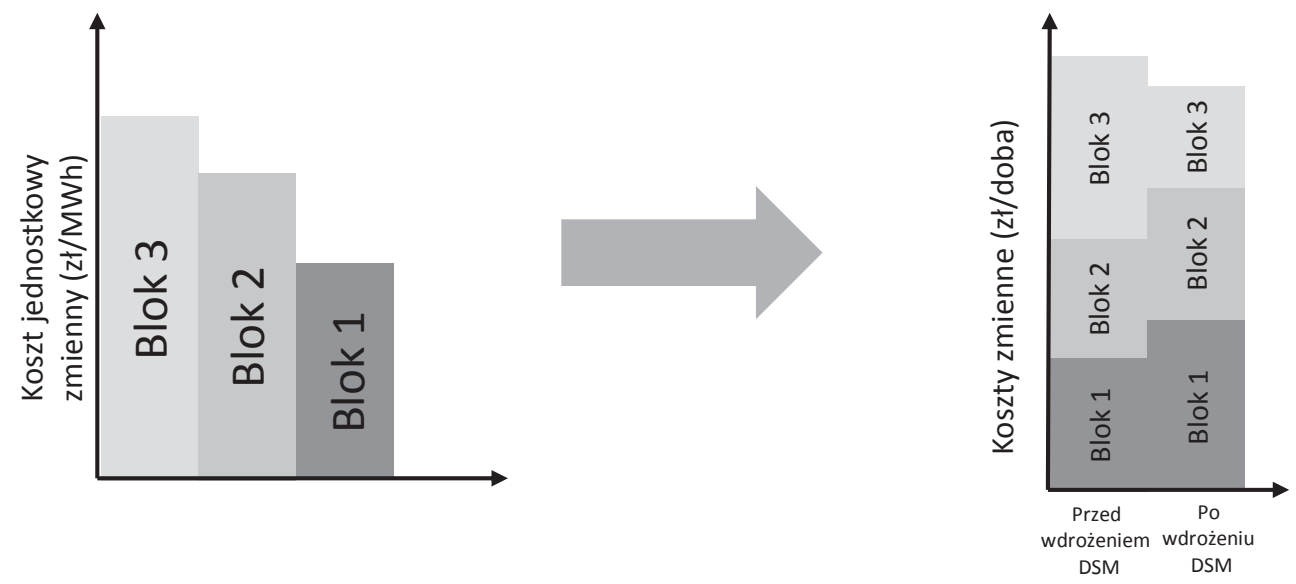

Rys. 4. Wpływ wdrożenia DSM na koszty zmienne

Źródło: opracowanie własne.

Podstawowym problemem optymalizacyjnym w krótkim czasie, zarówno przed, jak i po wdrożeniu systemu DSM, jest rozdział obciążeń (produkcji) pomiędzy jednostki wytwórcze. Kryterium optymalizacyjnym w krótkim okresie jest maksymalizacja marży pokrycia, rozumianej jako różnica pomiędzy przychodami ze sprzedaży energii elektrycznej a całkowitymi kosztami zmiennymi. Wzór na kalkulację tej marży dla dwóch wariantów kosztu jednostkowego zmiennego produkcji energii elektrycznej zaprezentowano poniżej:

1. Marża pokrycia generowana przez źródło z produkcji energii elektrycznej w ciągu doby przy stałych kosztach jednostkowych zmiennych jej produkcji przez poszczególne jednostki wytwórcze (bloki)

$$
\operatorname{Max} M P=\sum_{i=1}^{n}\left(c e_{i} \times \sum_{j=1}^{k} P_{j i}\right)-\sum_{j=1}^{k}\left(k_{j} \times \sum_{i=1}^{n} P_{j i}\right),
$$


gdzie: $n$ - liczba godzin w okresie (w ciągu doby), $i-i$-ta godzina, $k$ - liczba jednostek wytwórczych (bloków), $j-j$-ta jednostka wytwórcza (blok), $c e_{i}-$ cena energii elektrycznej w godzinie $i, P_{j i}-$ moc bloku $j$ w godzinie $i$ (produkcja energii elektrycznej przez blok $j$ w godzinie $i$ ), $k_{j}$ - koszt jednostkowy zmienny produkcji energii elektrycznej przez blok $j$.

2. Marża pokrycia generowana przez źródło z produkcji energii elektrycznej w ciągu doby przy zmiennych kosztach jednostkowych zmiennych jej produkcji przez poszczególne jednostki wytwórcze (bloki).

$$
\operatorname{Max} M P=\sum_{i=1}^{n}\left(c e_{i} \times \sum_{j=1}^{k} P_{j i}\right)-\sum_{j=1}^{k} \sum_{i=1}^{n} k_{j i} \times P_{j i}
$$

gdzie: $n$ - liczba godzin w okresie (w ciągu doby), $i-i$-ta godzina, $k$ - liczba jednostek wytwórczych (bloków), $j-j$-ta jednostka wytwórcza (blok), $c e_{i}-$ cena energii elektrycznej w godzinie $i, P_{j i}-$ moc bloku $j$ w godzinie $i$ (produkcja energii elektrycznej przez blok $j$ w godzinie $i$ ), $k_{j i}$ - koszt jednostkowy zmienny produkcji energii elektrycznej przez blok $j$ w godzinie $i$.

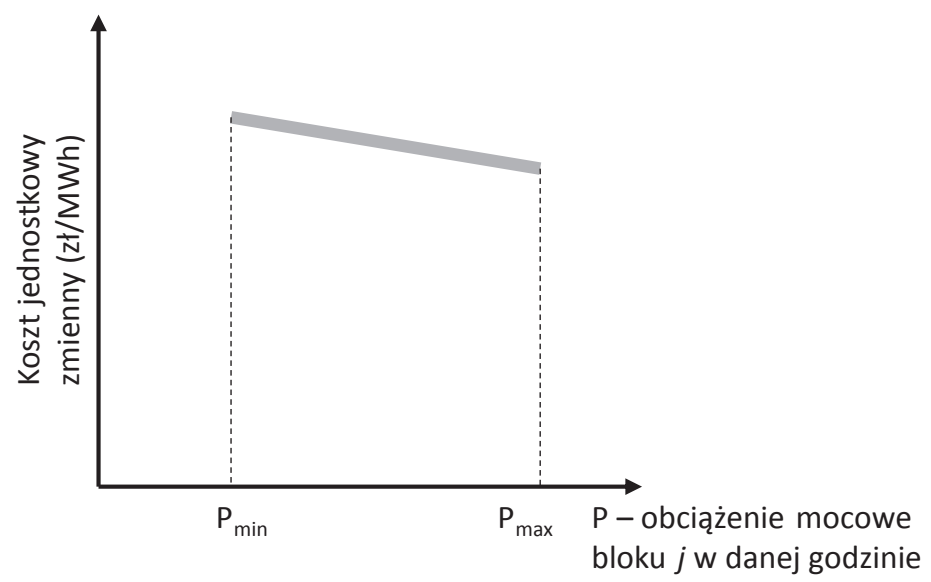

Rys. 5. Koszt jednostkowy zmienny produkcji energii elektrycznej przez blok $j$ w funkcji jego obciążenia

Źródło: opracowanie własne.

Bliższa rzeczywistości jest sytuacja druga, w której koszty jednostkowe zmienne produkcji energii elektrycznej przez poszczególne bloki zmieniają się wraz ze zmianą obciążenia danej jednostki wytwórczej w ciągu godziny. Im wyższa jest moc bloku, tym wyższa jest jego sprawność i niższy koszt jednostkowy zmienny produkcji energii elektrycznej. 
Niezależnie od wybranego modelu optymalizacyjnego funkcją celu jest maksymalizacja marży pokrycia w ciągu doby (w krótkim okresie). Zmiennymi w modelu optymalizacyjnym jest moc bloków w poszczególnych godzinach doby. Optymalizacja odbywa się jednak przy przyjęciu szeregu dodatkowych ograniczeń, zarówno rynkowych, jak i technicznych. Przede wszystkim suma mocy generowanej przez bloki w ciągu danej godziny nie może być większa od zakontraktowanej pozycji rynkowej źródła, czyli:

$$
\sum_{j=1}^{k} P_{j i}=P R_{i}
$$

gdzie: $i-i$-ta godzina, $k$ - liczba jednostek wytwórczych (bloków), $j-j$-ta jednostka wytwórcza (blok), $P R_{i}$ - zakontraktowana pozycja rynkowa źródła w godzinie $i, P_{j i}-$ moc bloku $j \mathrm{w}$ godzinie $i$ (produkcja energii elektrycznej przez blok $j$ w godzinie $i$ ).

Inne ograniczenia mają charakter techniczny i dotyczą między innymi:

- maksymalnej i minimalnej mocy poszczególnych jednostek wytwórczych (bloków): $P_{j \min }<P_{j}<P_{j \max }$,

- szybkości zwiększania i redukcji mocy poszczególnych bloków w czasie,

- dyspozycyjności poszczególnych jednostek wytwórczych.

Celem przedstawionej optymalizacji rozdziału obciążeń pomiędzy jednostki wytwórcze jest maksymalizacja marży pokrycia w ciągu krótkiego czasu. Wdrożenie systemu DSM może istotnie podnieść tę marżę w krótkim okresie ze względu na:

- wydłużenie w ciągu doby czasu pracy z większym obciążeniem jednostek wytwórczych o niższych kosztach jednostkowych zmiennych produkcji energii elektrycznej,

- skrócenie w ciągu doby czasu pracy z dużym obciążeniem jednostek wytwórczych o wyższych kosztach jednostkowych zmiennych produkcji energii elektrycznej.

Przy ogólnie niezmienionym popycie na energię elektryczną $\mathrm{w}$ ciągu doby (w wyniku wdrożenia DSM następuje jedynie przesunięcie popytu) wdrożenie systemu DSM może przełożyć się na spadek globalnych kosztów zmiennych produkcji energii elektrycznej w ciągu doby i tym samym na wzrost marży pokrycia oraz wyniku ze sprzedaży.

Drugim wymiarem systemu DSM jest jego związek ze strategicznym zarządzaniem kosztami w źródle energii. Wdrożenie systemu DSM w dużej skali przekłada się bowiem na redukcję zapotrzebowania na moc elektryczną w szczycie. Według różnych szacunków redukcja zapotrzebowania na moc w szczycie może wynieść od $10 \%$ do $15 \%$. Jeżeli ta redukcja ma charakter trwały, co jest możliwe przy dużej skali wdrożenia systemu DSM u odbiorców końcowych, a także przy jego konsekwentnym stosowaniu, to umożliwia ona zmianę podejścia do planowania utrzyma- 
nia i rozwoju mocy wytwórczych w źródle w długim okresie. Ponieważ planowanie utrzymania i rozwoju mocy wytwórczych w energetyce odbywa się w horyzoncie od 15 do 30, a nawet więcej lat, to wdrożenie systemu DSM jest wprost związane ze strategicznym zarządzaniem kosztami. Redukcja zapotrzebowania na moc w szczycie poprzez wdrożenie systemu DSM:

- w pierwszej kolejności przekłada się na ograniczenie nakładów na remonty i odtwarzanie mocy w najstarszych jednostkach wytwórczych o najniższej sprawności i najwyższych kosztach jednostkowych zmiennych,

- w drugiej kolejności przekłada się na ograniczenie nakładów inwestycyjnych na budowę mocy szczytowych.

Obie konsekwencje wdrożenia systemu DSM przekładają się w długim okresie na redukcję kosztów utrzymywania potencjału wytwórczego. Koszty stałe w energetyce są kosztami zdeterminowanymi (zapadłymi), które wynikają z decyzji inwestycyjnych dotyczących struktury i wysokości instalowanych mocy wytwórczych. Wdrożenie systemu DSM przekłada się zazwyczaj na ograniczenie tych kosztów, w tym przede wszystkim amortyzacji, kosztów remontów i utrzymania jednostek wytwórczych w dyspozycyjności, kosztów ich obsługi i ubezpieczenia. Jednocześnie ze względu na ograniczenie zainstalowanych mocy w jednostkach wytwórczych przy zachowaniu tego samego popytu na energię elektryczną po wdrożeniu systemu DSM (następuje jedynie przesunięcie popytu w ciągu doby) rośnie stopień wykorzystania potencjału produkcyjnego, co wprost przekłada się na spadek kosztów jednostkowych całkowitych produkcji energii elektrycznej i poprawę konkurencyjności wytwórców.

Jak z powyższego wynika, wdrożenie systemu DSM może istotnie przyczynić się do poprawy wyniku ze sprzedaży wytwórców energii elektrycznej. Zmianę tego wyniku w długim okresie można zapisać następująco:

$$
\Delta W=\Delta M P-\Delta K S,
$$

gdzie: $\Delta W$ - zmiana wyniku ze sprzedaży w okresie, $\Delta M P$ - zmiana marży pokrycia w okresie, $\triangle K S$ - zmiana kosztów stałych w okresie (spadek ze znakiem ujemnym).

Należy jednak pamiętać o tym, iż poprawa wyników wytwórców energii elektrycznej może nastąpić jedynie wówczas, gdy skala wdrożenia systemu DSM w systemie elektroenergetycznym jest wystarczająco szeroka. Zatem system ten musi być wdrożony u dużej liczby końcowych odbiorców energii elektrycznej, nie tylko tych największych, lecz także w małych i średnich przedsiębiorstwach oraz w gospodarstwach domowych. Osiągnięciu tego celu sprzyja jednak rozwój nowoczesnych technologii informatycznych, w tym koncepcji Internetu rzeczy (IoT). 


\section{Podsumowanie}

Systemy DSM umożliwiają wspomaganie zarządzania popytem na określony produkt po stronie odbiorcy. Niemniej jednak poprzez oddziaływanie na wielkość i strukturę popytu na produkt w czasie systemy te wpływają także na wysokość i strukturę kosztów przedsiębiorstwa. Przesunięcie popytu w czasie, szczególnie przy wykorzystaniu mechanizmu cen dynamicznych, może też oddziaływać na zwiększenie całkowitego popytu na dany produkt. Systemy DSM poprzez przesunięcie popytu w czasie przyczyniają się przede wszystkim do ograniczenia koniecznych do utrzymywania zdolności produkcyjnych czy zdolności do świadczenia usług przy zachowaniu lub nawet zwiększeniu całkowitej sprzedaży. Zatem systemy DSM przyczyniają się do zwiększenia stopnia wykorzystania zdolności produkcyjnych i do ograniczenia kosztów stałych ich utrzymywania. Oba te zjawiska prowadzą do zwiększenia efektywności.

Systemy DSM wywodzą się z rynku energii elektrycznej. Niemniej jednak w wyniku rozwoju technologii informatycznych i telekomunikacyjnych tego typu rozwiązania znajdują coraz częściej zastosowanie również w innych sektorach gospodarki. Szczególnie dynamicznie rozwijają się systemy DSM wykorzystujące ideę cen dynamicznych. Tego typu systemy mogą znaleźć zastosowanie we wszystkich tych sektorach, w których w krótkim czasie nie można zwiększyć zdolności produkcyjnych lub zdolności do świadczenia usług, a popyt na określony produkt nie jest rozłożony równomiernie w czasie. Zatem systemy DSM wykorzystujące ceny dynamiczne znalazły zastosowanie w zarządzaniu popytem w liniach lotniczych, hotelarstwie, a ostatnio znajdują także zastosowanie w rozwiązaniach z obszaru SmartCity. W tym ostatnim przypadku systemy DSM wykorzystujące ceny dynamiczne umożliwiają bardziej równomierne rozłożenie zapotrzebowania na usługi parkingowe czy dostęp samochodów do centrów miast. W godzinach szczytu ceny za usługi parkingowe czy za wjazd do centrum są znacznie wyższe niż w pozostałych godzinach doby. Co więcej, systemy te umożliwiają wprowadzanie nowych form płatności za te usługi, w tym płatności za rzeczywiście wykorzystany czas parkowania samochodu czy przebywania w centrum miasta.

\section{Literatura}

Behrangrad M., 2015, A review of demand - side management business models in the electricity market, Renewable and Sustainable Energy Reviews, 47, s. 270-283.

Gellings C.W., 1985, The concept of demand side management for electric utilities, Proceedings of the IEEE, 73, 10.

Kaplan R.S., Cooper R., 2000, Zarządzanie kosztami i efektywnościa, Dom Wydawniczy ABC. Oficyna Ekonomiczna, Kraków.

Nita B., 2008, Ewolucja rachunkowości zarzadczej: od rachunku kosztów do strategicznej rachunkowości zarządczej, Prace Naukowe Uniwersytetu Ekonomicznego we Wrocławiu, nr 14. 
Nowak E., 2015, Rachunek kosztów a zarządzanie kosztami. Rozważania o relacjach, Studia Ekonomiczne, Zeszyty Naukowe. Uniwersytet Ekonomiczny w Katowicach, nr 245.

Sharifi R., Fathi S.H., Vahidinasab V., 2017, A review on demand-side tools in electricity market, Renewable and Sustainable Energy Reviews, 72, s. 565-572.

Tuan L.A., Bhattacharya K., 2003, Competitive framework for procurement of interruptible load services, IEEE Transactions on Power Systems, vol. 18, May.

Warren P., 2014, A review of demand-side management policy in the UK, Renewable and Sustainable Energy Reviews, 29, s. 941-951.

Wierzbiński M., 2017, Zarządzanie kosztami, Prace Naukowe Uniwersytetu Ekonomicznego we Wrocławiu, nr 480. 